\title{
Modification of chiral dimethyl tartrate through transesterification: Immobilisation on POSS and enantioselectivity reversion in Sharpless asymmetric epoxidation
}

Rafael A. García, ${ }^{1 *}$ Rafael van Grieken, ${ }^{1}$ José Iglesias, ${ }^{1}$ David C. Sherrington, ${ }^{2}$ Colin L. Gibson $^{2}$

${ }^{1}$ Department of Chemical and Environmental Technology. Universidad Rey Juan Carlos. C/ Tulipán s/n. Móstoles. E28933. Madrid. Spain.

${ }^{2}$ Department of Pure and Applied Chemistry. Strathclyde University. Thomas Graham Building. 295 Cathedral St. Glasgow. G1 1XL. UK

* To whom correspondence should be addressed:

Ph: +34 914887068

e-mail: rafael.garcia@urjc.es 


\begin{abstract}
Modification of dimethyl tartrate has been investigated through transesterification with aminoalcohols to provide reactive functionalities for the covalent bonding of chiral tartrate to polyhedral oligomeric silsesquioxanes. The transesterification of dimethyl tartrate has been widely studied by means of using different catalytic systems and reaction conditions. Through the proper selection of both, the catalytic system and the reaction conditions, it is possible to achieve the mono- or the bis-substituted tartrate derivative as sole products. All the intermediate chiral tartrate-derived ligands were successfully used in the homogeneous enantioselective epoxidation of allylic alcohols providing moderate enantiomeric excess over the products. Attached amine groups have been used to support the modified tartrate ligands onto a haloaryl-functionalized silsesquioxane moiety. This final chiral tartrate ligand displays enantioselectivity reversion in the asymmetric epoxidation of allylic alcohols with regards to the starting dimethyl tartrate ligand, having both molecules them the same chiral sign. However, the POSS-containing ligand can be easily recovered in almost quantitative yield and reused in asymmetric epoxidation reactions. In addition, recovered silsesquioxane-pendant ligand, though displaying decreasing catalytic activity in recycling epoxidation tests, showed very stable enantioselective behavior.
\end{abstract}

Keywords: Tartrate ligands; Transesterification; Asymmetric epoxidation; Enantioselectivity reversal; POSS; 


\section{Introduction}

The development of the titanium-tartrate system as a chiral catalyst for the asymmetric epoxidation of allylic alcohols (Sharpless asymmetric epoxidation) has been one of the major breakthroughs in enantioselective synthesis [1]-[3], as revealed by the large number of publications related to this topic [4]. Thus, the asymmetric epoxidation of allylic alcohols has become a valuable tool for the synthesis of enantiopure epoxyalcohols, which are versatile chiral building blocks [5]-[6]. However, one of the main drawbacks of this process is the complexity of the work-up procedure for carrying out the oxidation and quenching the reaction. In this sense not only large amounts of solvents are necessary to purify the products, but also the reuse or recovery of the catalyst becomes impossible. Different attempts, more or less successful, have been carried out in order to overcome these inconveniencies. Some of them deal with the possibility of supporting the chiral ligands on different solids, both organic or inorganic, to obtain heterogeneous analogues to the Sharpless homogeneous catalyst [7]-[10]. In this way the quenching of the reaction is largely simplified, since the filtration of the catalysts is enough to stop the reaction and also the catalyst is reusable. However, the immobilization of the catalytic species leads, in most of the cases, to a great decrease of the catalytic activity because of mass transfer becomes a limiting stage of the reaction process. An interesting way to prepare reusable catalysts without introducing mass transfer restrictions consists of using a carrier for the catalytic active species which helps the recovering of the catalytic complex. One of the possibilities deals with the handling of polyhedral oligomeric silsesquioxanes - POSS - which easily dissolve or precipitate depending on the organic solvent, allowing their recovering. Silsesquioxanes are organosilicon compounds usually employed as models for the study of the behaviour of certain species immobilized onto the surface of silica-based supports. 
Those compounds have been applied to the immobilization of both, either metal species [11]-[13] or organic compounds [14],[15], giving an approximate idea of the catalytic behaviour of the grafted species onto the surface of solid supports. However, operating with these species simplifies the working procedures since, through the proper choice of the solvent, silsesquioxane can disolve to form homogeneous catalytic systems but they are easily recovered by selective precipitation in other solvents - usually THF -.

The work herein described presents the modification of chiral tartrate molecules, starting from dimethyl L-(+)-tartrate 1, suitable for covalent bonding to properly functionalized silsesquioxanes. This approach is based on the modification of the ester groups which minimizes the structural change with respect to catalyst enantioselectivity (Scheme 1). The enantiopure tartrate derived ligands were used, together with titanium isopropoxide, in the asymmetric epoxidation of various allylic alcohols, using tert-butyl hydroperoxide (TBHP) as oxidant agent, providing good asymmetric induction. Silsesquioxane-pendant tartrate ligand showed reversal enantioselective with regards non-modified tartrate in the epoxidation of cinnamyl alcohol, being this result attributed to the bulky size of the silicon substituent. Recycling test with POSS-functionalized tartrate ligands provided constant enantioselectivity though the activity decreases for reutilization runs.

\section{Results and Discussion}

Design and synthesis of mono (3) and di-amino (4) ester.

\section{Synthesis optimization}

For anchoring purposes on an appropriately functionalized silsesquioxane, $N$-methylethanolamine $\mathbf{2}$, was chosen as the amine functionality for carrying out a 
transesterification reaction. To avoid undesired reactions the hydroxylamine 2 was BOC protected to afford the carbamate 5 as colourless oil in $95 \%$ yield.

The starting material dimethyl L-tartrate 1, was first protected as the bisacetal by using 2,3-butanedione, accordingly to the methodology developed by Dixon et al. [16], yielding a white solid of (2,3,5,6)-dimethoxy-5,6-dimethyl-[1,4]-dioxane-dimethyl tartrate 6 in 90-95\% yield after purification by recrystallization, or by using dimethylbenzyl acetal, following the Seebach procedure [17], yielding a white solid of 2,3-Obenzyliden-dimethyl tartrate 7 , in $90-95 \%$ yield after recrystallization (Scheme 2). In both cases, the chirality of the starting tartrate was maintained. The use of different protecting group strategies was justified because of the different de-protection procedures to be employed. Thus, while the dimethoxy-[1,4]-dioxane protecting group in 6 may be removed by acid hydrolysis with trifluoroacetic acid (TFA), the benzylidine acetal in 7 may be removed by hydrogenolysis.

The next step in the tartrate modification protocol consisted of the transesterification of the protected starting materials $\mathbf{6}$ and 7. In this step both the mono $\mathbf{9}$ and $\mathbf{1 1}$ and disubstituted compounds $\mathbf{1 0}$ and $\mathbf{1 2}$ can be obtained (Scheme 3). For the synthesis of monosubstituted compounds 9 and 11, the acetals 6 and 7 were reacted with BOC ethanolamine $\mathbf{5}$ using a titanium alkoxide, following a similar procedure to that described by Dixon et al. [18]. N-methyl-tert-butoxycarbonylethanolamine $\mathbf{5}$, was treated with titanium tetrachloride in the presence of triethylamine as catalyst to give the corresponding titanium alkoxide, $\mathbf{8}$, (Scheme 4) to be used as a transesterification catalyst. The synthesis of $\mathbf{8}$ was targetted bearing in mind that transesterification reactions catalysed by titanium alkoxides take place by the alkoxide binding to the metallic center with transfer to the ester group [19] (Scheme 4). 
Table 1 sumarizes the results obtained for the transesterification of $\mathbf{6}$ and $\mathbf{7}$ with $\mathbf{5}$ using 8 as catalyst. The investigated titanium alkoxide to tartrate ratios seem to confirm the high catalytic activity of the titanium alkoxide $\mathbf{8}$, since better yields for the transesterification products are obtained as the titanium content increases (Table 1, entries 1-4). At this point it is noteworthy that the monosubstituted compound 9 is produced as the unique product with $\mathrm{Ti} /$ tartrate ratios of $0.05-0.15$ (Table 1 , entries 1-3). The influence of the solvent polarity on the product distribution has also been investigated (Table 1, entries 5 and 6). Thus, similar results were found when THF or chloroform were used, while the use of a non-polar solvent such as benzene led to a remarkable increase in the yield of the monoester $\mathbf{9}$, without detecting any presence of diester 10 (Table 1, entry 6). These results suggest a strong influence of the polarity of the solvent on the reaction outcome, since less polar solvents provide higher yields of transesterified product 9 .

Comparison between the two differently protected starting tartrates revealed that 7 was more reactive than $\mathbf{6}$ as evidenced from the shorter transesterification reaction times to achieve similar yields of $\mathbf{9}$ and $\mathbf{1 1}+\mathbf{1 2}$, respectively (Table 1, entries 6-7). The monitorization of the reaction media during the transtesterification reactions, did not reveal the presence of diester 10 when using 6 as starting material, unlike protected dimethyl tartrate 7, which leaded to diester 12 after few hours. This difference in behaviour could be probably explained by the smaller number of coordinating OR groups in 7, making the alkoxide more available.

Since the above described methodology is clearly effective in achieving selective monosubstitution, an alternative procedure was employed to synthesize the disubstituted products $\mathbf{1 0}$ and 12. A strongly acidic catalyst, n-butyl-stannonic acid, has been described as an effective catalyst for the transesterification reaction of diesters [20]. 
Bearing in mind the effect of the solvent in the monosubstitution transesterifications, benzene was used as the reaction solvent. These results are detailed in Table 2.

Increasing the molar ratio of 5:7 led to higher yields of $\mathbf{1 2}$ as the main product (Table 2,

entries 1, 2 and 3). Additionally, further improvements in the yield of diesters $\mathbf{1 0}$ and $\mathbf{1 2}$ were obtained by varying the catalyst amount. The effect of this parameter was more pronunced than altering the amine/DMT molar ratio. Here, the bis-substituted product 10 or 12 was the sole product when the Ti:substrate ratio is raised to 0.5:1 (Table, 2, entries 5 and 6).

The next step in the procedure was the removal of the protecting groups in $\mathbf{9 - 1 2}$, for which two different approaches were used (Scheme 5). In the first route each group was removed separately. Thus, the benzylidene acetal protecting group in modified tartrates 11 and 12 was firstly removed by hydrogenation, using the method described by Kocienski [21]. This procedure gave the corresponding diols $\mathbf{1 3}$ and $\mathbf{1 4}$ in 95\% yield after purification by preparative HPLC. Subsequent cleavage of the BOC protecting group was then carried out by acid hydrolysis with $\mathrm{CF}_{3} \mathrm{COOH}$. This gave the deprotected amine modified tartrates 3 and $\mathbf{4}$ in $70-85 \%$ yield after crystallization. Alternatively, a method similar to that developed by Dixon et al. [18] was used to remove the protecting groups from tartrates 9 and 10. Thus, attempted BOC and dimetoxy acetal deprotection was investigated using $\mathrm{CF}_{3} \mathrm{COOH}$ at r.t. However, using this procedure only the BOC protecting group was removed. It was found that a second treatment increasing the temperature and reaction time up to $24 \mathrm{~h}$ yielded the unprotected tartrate 3 and $\mathbf{4}$.

\section{Synthesis of silsesquioxane-pendant tartrate ligands}

In order to evaluate the behaviour of the tartrate derived compounds as chiral ligands, a step forward in terms of the synthesis of silsesquioxane immobilized ligands (Scheme 
6) has been carried out. Initially the haloaryl functionalized silsesquioxane was reacted with 2 to give product $\mathbf{1 5}$. The resultant product $\mathbf{1 5}$ displays, as did the protected compound $\mathbf{5}$, the ability to react only with the protected tartrate through the hydroxyl group. Thus, $\mathbf{1 5}$ was reacted with the benzilidene acetal protected dimethyl tartrate $\mathbf{7}$ to give the transester 16. Protected dimethyltartrate 7 was chosen as the starting material for this study because unlike the butanedione derivative 6, which requires strong acid treatment for its cleavage, the benzilidene acetal protecting group can be easily removed using mild hydrogenation conditions. In this way, the integrity of the rest of the molecule was ensured by the cleavage of 16 with $\mathrm{Pd} / \mathrm{C}$ to give 17 . All the steps of this sequence have led to similar results to that achieved for the analogue product 11, although butyl stannonic acid was used as catalyst for the transesterification reaction because of its readily availability and its capability to mainly produce symmetric bissubstituted tartrates through transesterification. The crude reaction was then submitted to hydrogenation in presence of $\mathrm{Pd} / \mathrm{C}$ as catalyst for the cleavage of the benzylidene acetal, giving product $\mathbf{1 7}$ as a white solid.

\section{Catalytic tests}

The enantioselective epoxidation of different allylic alcohols with tert-butyl hydroperoxide (TBHP) were performed at $-20^{\circ} \mathrm{C}$ in presence of either $3,4,13,14$ or 17 as chiral ligands and using $\mathrm{Ti}(\mathrm{O}-\mathrm{iPr})_{4}$ as titanium source. Ligands 13 and $\mathbf{1 4}$, containing the BOC protecting groups, were studied for comparison purposes, to contrast the enantio- and catalytic activity in ligands $\mathbf{3}$ and 4, showing free amino functionalities. These tests also allowed checking the different modifications carried out during consecutive protection, transesterification and deprotection reactions did not caused ligand razemization. The results have been summarized in table 3. 
The best activity and enantioselectivity were found for the BOC protected ligands $\mathbf{1 3}$ and 14 (Table 3, entries 3 and 4). Using ligand 14 as the chiral catalyst with titanium tetraisopropoxide gave the epoxy alcohol in up to $70 \%$ ee. In contrast, using tartrates with free amino group i.e. 3 and 4 (entries 1 and 2) led to the generation of lower epoxide yields and enantioselectivities, which could be caused by the formation of different titanium-tartrate derivative complexes when amino groups, free from protective group, are present within the chiral ligand. In general, these results are repeated for the different tested substrates, independently of the structure of the oxidized allylic alcohol. These results suggest only moderate efficiency in the formation of the tartrate-titanium complex, the essential active catalytic species for the Sharpless epoxidation catalyst.

On the other hand, it is particularly noteworthy that the tartrate-derived chiral ligand supported on silsesquioxane $\mathbf{1 7}$ shows a similar activity to that of the Boc-protected tartrate analogue, although the most interesting result for this reaction lies in the reversed enantioselectivity showed by this ligand. The measured enantiomeric excess is in the same range than using ligand $\mathbf{1 3}$, but the achieved chiral induction is completely reversed, yielding an excess of the opposite enantiomer to the major one achieved with the rest of the L-(+)-dimethyl tartrate derivatives. Enantioreversion has been previously observed in several ligands because of different reasons [22]-[28]. For instance, the molar ratio between components [22] or just the reaction solvent [25] causes the reversal on the enantioselectivity of a certain catalyst. Immobilising on polymer supports has also been described to produce reversal enantioselectivity [26],[27]. Actually, Janda et al. [27] found enantioreversal induction in the epoxidation of 2hexen-1-ol when using poly(ethylene glycol) transesterified chiral tartrates. These authors have shown that the Sharpless' catalyst enantioselection can be reversed 
depending on the size of the ester substituents at the tartrate ligands, so that if the size of the substituent is higher than 750 a.m.u. the sign of the optical rotation of the product is reversed. Bearing in mind the silsesquioxane fragment attached to the tartrate ligand is larger than 1,100 a.m.u., a similar enantioreversal behaviour could arise with this ligand as well. With regards to the reusability of the silsesquioxane-pendant tartrate chiral ligand, the same was recovered from the reaction media, after epoxidation of cynnamyl alcohol, by means of precipitation with THF, washed with dichloromethane and dryed before being used in a second assay (Table 3, entry 6). Results indicate the enantioselectivity of the complex is well preserved during the recycling test, leading to the same enantiomeric excess on the final glycidol product. On the other hand, the catalytic activity is largely decreased for the reutilization test, since less than a half of the initial epoxide yield is achieved. This loss of catalytic activity could be related to the inactivation of some fraction of the chiral complex during the recycling test. Preliminary results on the epoxidation of different allylic alcohols indicate a similar behaviour for other substrates, finding the same enantioselective reversion observed for cinnamyl alcohol

Finally, in order to determine whether this is the cause of enantioreversion or just the presence of the benzyl group in the aminoalcohol used for transesterifying the chiral tartrate ligand, a new compound was prepared. In this case, N-benzyl N-methyl amino ethanol was used for the transesterification of dimethyl tartrate starting from 7 and carrying out the transesterification reaction in presence of butylstannonic acid (Scheme 7). The resultant product, obtained after acetal cleavage, $\mathbf{1 8}$ was used as chiral ligand in the asymmetric epoxidation of cinnamyl alcohol inducing the usual chiral configuration onto the resultant phenyl glycidol (Table 3, entry 7). In this way, the enantioselectivity 
reversal observed for the POSS-functionalized material should be ascribed to the size of the silsesquioxane fragment more than to the presence of the aromatic ring.

\section{Conclusions}

A straightforward strategy for modifying tartrates has been developed in order to attach the resultant chiral ligands onto properly-functionalized polyhedral oligomeric silsesquioxanes. The reaction conditions for transesterification were optimized to achieve either the mono- or bis-substituted tartrate derivative as the sole product. The chiral tartrate-derived ligands so-obtained were used in the asymmetric epoxidation of cinnamyl alcohol achieving up to $70 \%$ ee in the resulting epoxy-alcohol. C2symmetrical diesters $\mathbf{4}$ and $\mathbf{1 4}$ gave higher enantiomeric excess than the asymmetric monosubstituted tartrate derivatives 3 and 13. Finally, the amino-groups allowed anchoring the tartrate derived ligands to a silsesquioxane fragment resulting in a enantioselectivity reversal of the chiral ligand. Further studies on the application of this heterogeneization strategy to the anchoring of tartrate derived ligands onto the surface of silica supports are being developed.

\section{Experimental}

Materials and general procedures.

Dimethyl-L-tartrate (DMT, Acros, +99\%) and N-methyl ethanolamine (NMEA, Aldrich, 99\%) were distilled under inert atmosphere before being used. N-butyl tin hydroxide oxide (Aldrich, 97\%) was used as received. Titanium chloride was used and stored in dry box. Tert-butyl hydroperoxide anhidrous solution in dichloromethane was prepared from acqueous solution (TBHP, Aldrich, 70\%) by extraction with 
dichloromethane followed by azeotropic distillation in a dean-stark for solvents heavier than water. The obtained solution was characterized by iodometric titration and stored at low temperature $\left(+4^{\circ} \mathrm{C}\right)$ in presence of activated $3 \AA$ molecular sieves.

All non-aqueous reactions were carried out under inert atmosphere (usually nitrogen or argon) using standard Schlenk techniques, avoiding all times the presence of traces of water in the starting materials. Solvents were distilled prior their use as follows: $\mathrm{CHCl}_{3}$ from $\mathrm{P}_{2} \mathrm{O}_{5}$; THF from $\mathrm{Na} /$ benzophenone; benzene and toluene from $\mathrm{Na}$. Melting points were determined using a Mettler Toledo DSC822e. NMR spectra were recorded on a Varian Mercury $400 \mathrm{MHz}$ spectrometer. Chemical shifts are reported in parts per million (ppm), in reference to the residual proton signals from the deuterated solvents. FTIR analysis were acquired on a Mattson Infinity series FT-IR spectrometer using the $\mathrm{KBr}$ buffer technique. Elemental analyses were performed on a Elementar Vario EL III. TLC was carried out using precoated sheets (Aldrich silica gel) and visualizing the products by developing with phosphomolybdic acid/ethanol or ammonium molybdate and cerric sulphate in $\mathrm{H}_{2} \mathrm{SO}_{4} / \mathrm{H}_{2} \mathrm{O}$ [28]. Product purification was carried out, unless otherwise stated, on a semi-preparative scale HPLC Varian Prepstar fitted with a normal phase Dynamax Microsorb 100-8 Si column (250 mm length, $41.4 \mathrm{~mm}$ I.D.) using n-hexane:i-propanol mixtures as solvent.

Protection of starting materials

tert-Butyl 2-hydroxyethyl(methyl)carbamate (5). To a solution of 2 (10 g, $0.133 \mathrm{~mol})$ in THF (50 ml) at $0^{\circ} \mathrm{C}$, was added a solution of di-tert-butyl dicarbonate (32 $\left.\mathrm{g}, 0.146 \mathrm{~mol}\right)$ in THF $(10 \mathrm{ml})$ dropwise. The reaction mixture was stirred overnight at room temperature and then concentrated in vacuo. The residue was purified by semipreparative HPLC to give the title compound (21.5 g, $0.123 \mathrm{~mol}, 92 \%) .{ }^{1} \mathrm{H}$ NMR (400 $\left.\mathrm{MHz}, \mathrm{CDCl}_{3}\right): \delta=1.36\left(\mathrm{~s}, 9 \mathrm{H} ;-\mathrm{C}\left(\mathrm{CH}_{3}\right)_{3}\right), 2.82\left(\mathrm{~s}, 3 \mathrm{H} ;-\mathrm{N}-\mathrm{CH}_{3}\right), 3.25\left(\mathrm{~m}, 2 \mathrm{H} ;-\mathrm{N}-\mathrm{CH}_{2}-\right)$; 
$3.61 \mathrm{ppm}\left(\mathrm{m}, 2 \mathrm{H} ;-\mathrm{CH}_{2}-\mathrm{OH}\right) .{ }^{13} \mathrm{C} \mathrm{NMR}\left(100 \mathrm{MHz}, \mathrm{CDCl}_{3}\right): \delta=28.2\left(-\mathrm{C}\left(\mathrm{CH}_{3}\right)_{3}\right), 34.9$ $\left(-\mathrm{N}-\mathrm{CH}_{3}\right), 51.3\left(-\mathrm{CH}_{2}-\mathrm{OH}\right), 60.8\left(-\mathrm{N}-\mathrm{CH}_{2}-\right), 79.5\left(-\mathrm{C}\left(\mathrm{CH}_{3}\right)_{3}\right), 156.7$ ppm $\left(-\mathrm{N}-\mathrm{CO}_{2}-\mathrm{tBu}\right)$. IR $v_{\max }\left(\right.$ neat): $1682(\mathrm{C}=\mathrm{O}), 2975(\mathrm{C}-\mathrm{H}), 3435 \mathrm{~cm}^{-1}(\mathrm{O}-\mathrm{H})$. Elemental analysis calcd (\%) for $\mathrm{C}_{8} \mathrm{H}_{17} \mathrm{NO}_{3}$ : C 54.84, H 9.78, N, 7.99; found: C 54.81, H 9.77, N 8.03.

Dimethyl (2R,3R,5R',6R') 5,6-dimethoxy-5,6-dimethyl-1,4-dioxane-2,3-dicarboxylate (6). To a solution of $\mathbf{1}(10.0 \mathrm{~g}, 55.6 \mathrm{mmol})$, trimethylorthoformate (TMOF, $17.8 \mathrm{~g}$, $166.9 \mathrm{mmol})$ and 2,3-butanodione $(6.0 \mathrm{~g}, 67.6 \mathrm{mmol})$ in methanol, was added camphorsulfonic acid (CSA, $1.3 \mathrm{~g}, 54.8 \mathrm{mmol}$ ). The mixture was then heated under reflux and stirring was continued overnight. The reaction was quenched by slow addition of $\mathrm{NaHCO}_{3}(10 \mathrm{~g}, 119 \mathrm{mmol})$ and reflux was maintained for two more hours. The resultant suspension was filtered and concentrated to dryness, giving a brown solid. The residue was then purified by recrystallization from n-hexane/ethyl acetate to give the desired product as a white solid (14.3 g, 49,0 mmol, 88.1\%). m.p. $105.2^{\circ} \mathrm{C} .{ }^{1} \mathrm{H}$ NMR (400 MHz, $\left.\mathrm{CDCl}_{3}\right): \delta=1.34\left(\mathrm{~s}, 6 \mathrm{H} ;-\mathrm{C}-\mathrm{CH}_{3}\right), 3.30\left(\mathrm{~m}, 6 \mathrm{H} ;-\mathrm{O}-\mathrm{CH}_{3}\right), 3.75(\mathrm{~s}, 6 \mathrm{H}$; $\left.-\mathrm{CO}_{2} \mathrm{CH}_{3}\right), 4.51 \mathrm{ppm}\left(\mathrm{m}, 2 \mathrm{H}\right.$; -O-CH-). ${ }^{13} \mathrm{C} \mathrm{NMR}\left(100 \mathrm{MHz}, \mathrm{CDCl}_{3}\right): \delta=17.4(-\mathrm{C}-$ $\left.\mathrm{CH}_{3}\right), 48.5\left(-\mathrm{O}-\mathrm{CH}_{3}\right), 52.5\left(-\mathrm{CO}_{2} \mathrm{CH}_{3}\right), 68.7(-\mathrm{O}-\mathrm{CH}-), 99.0\left(\mathrm{C}-\mathrm{CH}_{3}\right), 168.1$ ppm ($\left.\mathrm{CO}_{2} \mathrm{CH}_{3}\right) . \mathrm{IR} \mathrm{U}_{\max }(\mathrm{KBr}): 1030,1141,1204,1756(\mathrm{C}=\mathrm{O}), 2956(\mathrm{C}-\mathrm{H}) \mathrm{cm}^{-1}$. Elemental analysis calcd (\%) for $\mathrm{C}_{12} \mathrm{H}_{20} \mathrm{O}_{8}$ : C 49.31, H 6.90; found: C 49.47, H 6.94.

Dimethyl (4R,5R) 2-phenyl-1,3-dioxolane-4,5-dicarboxylate (7). A solution of 1 (10.0 $\mathrm{g}, 55.6 \mathrm{mmol})$ was mixed with benzaldehyde dimethyl acetal $(9.4 \mathrm{~g}, 61.1 \mathrm{mmol})$ in benzene $(50 \mathrm{ml})$. To this mixture was added p-toluenesulfonic acid $(0.05 \mathrm{~g}, 0.3 \mathrm{mmol})$ in a $100 \mathrm{ml}$ round bottom flask connected to Dean-Stark apparatus for solvents lighter than water. The mixture was heated under reflux for 12 hours during which time the solvent was withdrawn from the Dean-Stark trap in order to displace the equilibrium. The reaction was allowed to cool and then quenched with $\mathrm{K}_{2} \mathrm{CO}_{3}(4.2 \mathrm{~g}, 30.0 \mathrm{mmol})$. 
The resultant suspension was filtered and concentrated in vacuo to give a yellowish solid. The residue was recrystallized from $\mathrm{CH}_{2} \mathrm{Cl}_{2} /$ n-hexane to give compound 7 (13.1 g, 49 mmol, 89\%). m.p. $73.2^{\circ} \mathrm{C} .{ }^{1} \mathrm{H}$ NMR (400 MHz, $\left.\mathrm{CDCl}_{3}\right): \delta=3.84(\mathrm{~s}, 3 \mathrm{H}$; $\left.-\mathrm{CO}_{2} \mathrm{CH}_{3}\right), 3.89\left(\mathrm{~s}, 3 \mathrm{H} ;-\mathrm{CO}_{2} \mathrm{CH}_{3}\right), 4.92(\mathrm{~d}, 2 \mathrm{H}, \mathrm{J}=4.0 \mathrm{~Hz} ;-\mathrm{O}-\mathrm{CH}-), 6.15(\mathrm{~s}, 1 \mathrm{H} ;-\mathrm{CH}-$ $\mathrm{Ph}) ; 7.47 \mathrm{ppm}(5 \mathrm{H} ; \mathrm{HAr}) .{ }^{13} \mathrm{C}$ NMR $\left(100 \mathrm{MHz}, \mathrm{CDCl}_{3}\right): \mathrm{d}=52.9\left(-\mathrm{CO}_{2} \mathrm{CH}_{3}\right), 76.7$ (-OCH-), $106.6(C H-P h), 127.0,128.2$ and 129,9 $\left(\mathrm{HC}^{\mathrm{Ar}}\right), 135.0\left(\mathrm{C}^{\mathrm{Ar}}\right), 169.8\left(-\mathrm{CO}_{2} \mathrm{CH}_{3}\right) . \mathrm{IR}$ $\mathrm{U}_{\max }(\mathrm{KBr}): 1108,1244,1435,1754(\mathrm{C}=\mathrm{O}), 2958(\mathrm{C}-\mathrm{H}) \mathrm{cm}^{-1}$. Elemental analysis calcd (\%) for $\mathrm{C}_{13} \mathrm{H}_{14} \mathrm{O}_{6}$ : C 58.65, H 5.30; found: C 58.40, H 5.37.

Preparation of transesterification catalyst: (2-Methyl-boc-amino)ethyl orthotitanate (8). To a solution of $\mathrm{TiCl}_{4}(0.10 \mathrm{~g}, 0.53 \mathrm{mmol})$ in $\mathrm{CHCl}_{3}(10 \mathrm{ml})$, was added $5(0.37 \mathrm{~g}, 2.1$ mmol) dropwise to give a yellowish solution. The resultant mixture was then stirred for $30 \mathrm{~min}$ and then triethylamine $(0.21 \mathrm{~g}, 2.1 \mathrm{mmol})$ was added via syringe, giving a colourless suspension. The reaction was then stirred for an additional hour before being used as catalyst for transesterification reactions without further purification.

Transesterification Products

Transesterification reactions were carried out by mixing acetal proctected DMT, 6 or 7 (3.5 mmol scale), and compound 5 (3.5 mmol for monosubstitution reactions, $7.7 \mathrm{mmol}$ for disubstitution reactions) in dry solvents $(200 \mathrm{ml})$, typically benzene. To the resultant mixtures were added the transesterification catalysts: compound $8(0.53 \mathrm{mmol})$ and butylstannonic acid $(1.7 \mathrm{mmol})$ for the mono- and disubtitution reactions respectively. The so-prepared suspensions were then heated at reflux for 1 to 3 days, then filtered off through a column of florisil to remove the organometallic species and concentrated in vacuo. The residues were purified by semi-preparative scale HPLC and the fractions were collected for the main products. In each case the resultant fractions were concentrated in vacuo to give the following products: 
$2\{2-[($ tert-butoxycarbonyl)(methyl)amino]ethyl $\}$-3-methyl (2R,3R) 5,6-dimethoxy 5,6dimethyl-1,4-dioxane-2,3-dicarboxylate (9). Compound obtained as a colourless oil (1.43 g, $3.2 \mathrm{mmol}, 93 \%)$ starting from 6. ${ }^{1} \mathrm{H} \mathrm{NMR}\left(400 \mathrm{MHz}, \mathrm{CDCl}_{3}\right): \mathrm{d}=1.33(\mathrm{~s}, 6 \mathrm{H}$; C-CH $\left.H_{3}\right), 1.44\left(\mathrm{~s}, 9 \mathrm{H} ;-\mathrm{C}\left(\mathrm{CH}_{3}\right)_{3}\right), 2.90\left(\mathrm{~s}, 3 \mathrm{H} ; \mathrm{CH}_{3}-\mathrm{N}-\right), 3.30\left(\mathrm{~s}, 6 \mathrm{H} ;-\mathrm{O}-\mathrm{CH}_{3}\right), 3.45(\mathrm{~m}$, $2 \mathrm{H}$; -N-CH $\left.2^{-}\right), 3.74\left(\mathrm{~s}, 3 \mathrm{H} ;-\mathrm{CO}_{2} \mathrm{CH}_{3}\right), 4.24$ (m, 2H; - $\left.\mathrm{CH}_{2}-\mathrm{O}-\right), 4.50$ ppm (m, 2H; - $\mathrm{CH}-$ O-). ${ }^{13} \mathrm{C}$ NMR $\left(100 \mathrm{MHz}, \mathrm{CDCl}_{3}\right): \mathrm{d}=17.5\left(-\mathrm{C}-\mathrm{CH}_{3}\right), 28.7\left(-\mathrm{C}\left(\mathrm{CH}_{3}\right)_{3}\right), 35.5\left(-\mathrm{N}-\mathrm{CH}_{3}\right)$, $47.3\left(-\mathrm{N}-\mathrm{CH}_{2}-\right), 48.4$ (-O-CH 3$), 52.4$ (- $\left.\mathrm{CO}_{2} \mathrm{CH}_{3}\right), 64.2$ (- $\left.\mathrm{CH}_{2}-\mathrm{O}-\right)$, 68.7 (-CH-O-), 80.0 ($\left.C\left(\mathrm{CH}_{3}\right)_{3}\right), 99.2\left(-C-\mathrm{CH}_{3}\right), 154.9\left(-\mathrm{N}-\mathrm{CO}_{2} \mathrm{tBu}\right), 167.9 \mathrm{ppm}\left(-\mathrm{CO}_{2}-\mathrm{R}\right) . \mathrm{IR} \mathrm{v}_{\max }$ (neat): 1043, 1153, 1394, 1459, 1700, 1749, $2959 \mathrm{~cm}^{-1}$. Elemental analysis calcd (\%) for $\mathrm{C}_{19} \mathrm{H}_{33} \mathrm{NO}_{10}$ : C 52.40, H 7.64, N 3.22; found: C 51.96, H 7.52, N 3.35.

Bis $\{2-[($ tert-butoxycarbonyl)(methyl)amino]ethyl $\} \quad(2 R, 3 R)-5,6$-dimethoxy-5,6-dimethyl1,4-dioxane-2,3-dicarboxylate (10). This compound was obtained as a colourless oil (2.00 g, $3.47 \mathrm{mmol}, 99 \%)$ starting from 6. ${ }^{1} \mathrm{H}$ NMR (400 MHz, $\left.\mathrm{CDCl}_{3}\right): \mathrm{d}=1.30(\mathrm{~m}$, 6H; -C-CH $)_{3}, 1.42\left(\mathrm{~s}, 18 \mathrm{H} ;-\mathrm{C}\left(\mathrm{CH}_{3}\right)_{3}\right), 2.91\left(\mathrm{~s}, 6 \mathrm{H} ; \mathrm{CH}_{3}-\mathrm{N}-\right), 3.43\left(\mathrm{~m}, 4 \mathrm{H} ;-\mathrm{N}-\mathrm{CH}_{2}-\right)$, 4.22 (m, 4H; -CH2-O-), 4.47 ppm (2H; -CH-O-). ${ }^{13} \mathrm{C}$ NMR (100 MHz, $\left.\mathrm{CDCl}_{3}\right): \mathrm{d}=17.7$ $\left(-\mathrm{C}-\mathrm{CH}_{3}\right), 28.6\left(-\mathrm{C}\left(\mathrm{CH}_{3}\right)_{3}\right), 35.8\left(-\mathrm{N}-\mathrm{CH}_{3}\right), 48.6\left(-\mathrm{N}-\mathrm{CH}_{2}-\right), 52.8\left(-\mathrm{O}-\mathrm{CH}_{3}\right), 64.4\left(-\mathrm{CH}_{2}-\right.$ O-), 68.6 (-CH-O-), $80.1\left(-C\left(\mathrm{CH}_{3}\right)_{3}\right), 99.4\left(-\mathrm{C}-\mathrm{CH}_{3}\right), 155.8\left(-\mathrm{N}-\mathrm{CO}_{2} \mathrm{tBu}\right), 167.9$ ppm ($\mathrm{CO}_{2}-\mathrm{CH}_{2}$-). Elemental analysis calcd (\%) for $\mathrm{C}_{26} \mathrm{H}_{46} \mathrm{~N}_{2} \mathrm{O}_{12}: \mathrm{C}$ 53.97, $\mathrm{H}$ 8.01, N 4.84; found: C 54.12, H 7.88, N 4.65.

4-\{2-[(tert-butoxycarbonyl)(methyl)amino]ethyl\}-5-methyl (4R,5R)-2-phenyl-1,3dioxolane-4,5-dicarboxylate (11). This compound was obtained as a colourless oil (0.72 g, $1.76 \mathrm{mmol}, 46.8 \%)$ starting from 7. ${ }^{1} \mathrm{H}$ NMR $\left(400 \mathrm{MHz}, \mathrm{CDCl}_{3}\right): \mathrm{d}=1.41(\mathrm{~m}, 9 \mathrm{H} ;$ $\left.\mathrm{C}\left(\mathrm{CH}_{3}\right)_{3}\right), 2.86\left(\mathrm{~s}, 3 \mathrm{H} ; \mathrm{CH}_{3}-\mathrm{N}-\right), 3.28\left(\mathrm{~s}, 2 \mathrm{H} ;-\mathrm{N}-\mathrm{CH}_{2}-\right), 3.88\left(\mathrm{~m}, 3 \mathrm{H} ;-\mathrm{CO}_{2} \mathrm{CH}_{3}\right), 4.24$ (m, 2H; -CH2-O-), 4.86 (m, 2H; -CH-O-), 6.07 (s, 1H; -CH-Ph), 7.42 ppm (m, 5H; HAr $) .{ }^{13} \mathrm{C} \mathrm{NMR}\left(100 \mathrm{MHz}, \mathrm{CDCl}_{3}\right): \mathrm{d}=28.6\left(-\mathrm{C}\left(\mathrm{CH}_{3}\right)_{3}\right), 35.3\left(-\mathrm{N}-\mathrm{CH}_{3}\right), 47.4\left(-\mathrm{N}-\mathrm{CH}_{2}-\right.$ 
), $52.8\left(-\mathrm{CO}_{2} \mathrm{CH}_{3}\right), 63.7$ (- $\left.\mathrm{CH}_{2}-\mathrm{O}-\right), 77.7$ (-CH-O-), 80.1 (-C(CH3) $\left.)_{3}\right), 98.9$ (-CH-Ph), 126.7, 127.6 and $129.2\left(\mathrm{H} C^{\mathrm{Ar}}\right), 135.2\left(C^{\mathrm{Ar}}\right), 155.2\left(-\mathrm{N}-\mathrm{CO}_{2} \mathrm{tBu}\right), 167.9 \mathrm{ppm}\left(-\mathrm{CO}_{2} \mathrm{R}\right)$. Elemental analysis calcd (\%) for $\mathrm{C}_{20} \mathrm{H}_{27} \mathrm{NO}_{8}$ : C 58.67, H 6.65, N 3.42; found: C 58.55, H 6.63, N 3.57.

Bis $\{2-[($ tert-butoxycarbonyl)(methyl)amino]ethyl\} $\quad$ (4R,5R)-2-phenyl-1,3-dioxolane-4,5dicarboxylate (12). This compound was obtained as a colourless oil (1.91 g, $3.46 \mathrm{mmol}$, 92\%) starting from 7. ${ }^{1} \mathrm{H}$ NMR $\left(400 \mathrm{MHz}, \mathrm{CDCl}_{3}\right): \mathrm{d}=1.43\left(\mathrm{~s}, 18 \mathrm{H} ;-\mathrm{C}\left(\mathrm{CH}_{3}\right)_{3}\right), 2.91$ (s, 6H; $\left.\mathrm{CH}_{3}-\mathrm{N}-\right), 3.46\left(\mathrm{~m}, 4 \mathrm{H} ;-\mathrm{N}_{-} \mathrm{CH}_{2}-\right), 4.30\left(\mathrm{~m}, 4 \mathrm{H} ;-\mathrm{CH}_{2}-\mathrm{O}-\right), 4.92(\mathrm{~d}, 2 \mathrm{H}$; $J=17.9 \mathrm{~Hz},-\mathrm{CH}-\mathrm{O}-), 6.09$ (s, 1H; -CH-Ph), $7.44 \mathrm{ppm}(\mathrm{m}, 5 \mathrm{H} ; H \mathrm{Ar}) .{ }^{13} \mathrm{C}$ NMR (100 $\left.\mathrm{MHz}, \mathrm{CDCl}_{3}\right): \mathrm{d}=28.7\left(-\mathrm{C}\left(\mathrm{CH}_{3}\right)_{3}\right), 35.8\left(-\mathrm{N}-\mathrm{CH}_{3}\right), 47.8\left(-\mathrm{N}-\mathrm{CH}_{2}-\right), 64.4\left(-\mathrm{CH}_{2}-\mathrm{O}-\right)$, 77.7 (-CH-O-), $80.3\left(-\mathrm{C}\left(\mathrm{CH}_{3}\right)_{3}\right), 107.0(-\mathrm{CH}-\mathrm{Ph}), 127.4,128.5$ and $130.1\left(\mathrm{HC}^{\mathrm{Ar}}\right), 135.6$ $\left(C^{\mathrm{Ar}}\right), 155.3\left(-\mathrm{N}-\mathrm{CO}_{2} \mathrm{tBu}\right), 169.3 \mathrm{ppm}\left(-\mathrm{CO}_{2} \mathrm{CH}_{3}\right)$. Elemental analysis calcd (\%) for $\mathrm{C}_{27} \mathrm{H}_{40} \mathrm{~N}_{2} \mathrm{O}_{10}$ : C 58.68, H 7.30, N 5.07; found: C 58.32, H 7.78, N 4.98.

Bis $\{2-[($ benzyl)(methyl)amino]ethyl $\} \quad(2 R .3 R)-2,3-$ dihydroxybutanedioate (18). This compound was obtained as a yellowish oil (2.06 g, $3.46 \mathrm{mmol}, 92 \%)$ starting from 7 and subsequent deprotection with $\mathrm{Pd} / \mathrm{C}$ in ethanol. The product was purified by flash chromatography on silica with hexane:diethyl ether 50:50 vol. ${ }^{13} \mathrm{C}$ NMR $(100 \mathrm{MHz}$, $\left.\mathrm{CDCl}_{3}\right): \mathrm{d}=39.5\left(-\mathrm{N}-\mathrm{CH}_{3}\right), 54.8\left(-\mathrm{N}-\mathrm{CH}_{2}-\right), 60.5\left(-\mathrm{N}-\mathrm{CH}_{2}-\mathrm{Ph}\right), 62.1\left(-\mathrm{CH}_{2}-\mathrm{O}-\right), 74.1(-$ CH-O-), 126.7, 128.1 snf $128.6\left(\mathrm{HC}^{\mathrm{Ar}}\right), 135.6\left(C^{\mathrm{Ar}}\right), 137.7\left(-C^{\mathrm{Ar}}\right), 169.0$ ppm ($\mathrm{CO}_{2} \mathrm{CH}_{2-}$ ). Elemental analysis calcd (\%) for $\mathrm{C}_{24} \mathrm{H}_{32} \mathrm{~N}_{2} \mathrm{O}_{6}: \mathrm{C} 64.85, \mathrm{H}$ 7.26, N 6.30; found: C 64.98, H 7.27, N 6.32.

Cleavage of transesterification products 
After transesterification reactions and with the purpose of using modified tartrates as chiral ligands in the asymmetric epoxidation of cinnamyl alcohol, the protecting groups were removed as follows:

i) Benzyl acetal protected transesters were treated with catalytic amounts $\mathrm{Pd} / \mathrm{C}(10 \%)$ in methanol under $\mathrm{H}_{2}$ atmosphere for at least $24 \mathrm{~h}$. The reactions were carried out until no substrate was detected by TLC and then filtered and concentrated in vacuo.

ii) The 2,3-butanedione and $\mathrm{BOC}$ protecting groups were removed by acid treatment with TFA in $\mathrm{CH}_{2} \mathrm{Cl}_{2}$. The reactions were carried out in ultrasonic bath until completion and then concentrated in vacuo. The resultant products were purified by crystallization from $\mathrm{MeOH} / \mathrm{CH}_{2} \mathrm{Cl}_{2}$ at $-30^{\circ} \mathrm{C}$.

1-\{2-[(tert-butyoxycarbonyl)(methyl)amino]ethyl $\} \quad$ 4-methyl $\quad(2 R .3 R)-2,3-$ dihydroxybutanedioate (13). Starting from $11(1.0 \mathrm{~g}, 2.44 \mathrm{mmol})$ and using deprotection procedure $\mathrm{i})$, the title product was obtained as a light yellow oil $(0.78 \mathrm{~g}, 2.43 \mathrm{mmol}$, 99\%). ${ }^{1} \mathrm{H}$ NMR (400 MHz, DMSO-D 3$): \mathrm{d}=1.38$ (s, 9H; $\left.-\mathrm{C}\left(\mathrm{CH}_{3}\right)_{3}\right), 2.80\left(\mathrm{~s}, 3 \mathrm{H} ; \mathrm{CH}_{3}-\right.$ $\mathrm{N}-), 3.41\left(\mathrm{~m}, 2 \mathrm{H} ;-\mathrm{N}-\mathrm{CH}_{2}-\right), 3.64\left(\mathrm{~s}, 3 \mathrm{H} ;-\mathrm{CO}_{2} \mathrm{CH}_{3}\right), 4.15(2 \mathrm{xt}, 2 \mathrm{H} ; J=4.8 \mathrm{~Hz}, J=11.8 \mathrm{~Hz}$, $\left.J=17.4 \mathrm{~Hz},-\mathrm{CH}_{2}-\mathrm{O}-\right), 4.39 \mathrm{ppm}(\mathrm{m}, 2 \mathrm{H} ;-\mathrm{CH}-\mathrm{OH}) .{ }^{13} \mathrm{C}$ NMR $\left(100 \mathrm{MHz}, \mathrm{DMSO}-\mathrm{D}_{3}\right): \mathrm{d}$ $=27.6\left(-\mathrm{C}\left(\mathrm{CH}_{3}\right)_{3}\right) ; 33.8\left(-\mathrm{N}-\mathrm{CH}_{3}\right) ; 46.7\left(-\mathrm{N}-\mathrm{CH}_{2}-\right) ; 51.2\left(-\mathrm{CO}_{2} \mathrm{CH}_{3}\right) ; 62.0\left(-\mathrm{CH}_{2}-\mathrm{O}-\right)$; $72.1(-\mathrm{CH}-\mathrm{OH}) ; 78.3\left(-\mathrm{C}\left(\mathrm{CH}_{3}\right)_{3}\right) ; 153.8\left(-\mathrm{N}-\mathrm{CO}_{2} \mathrm{tBu}\right) ; 170.7$ ppm $\left(-\mathrm{CO}_{2} \mathrm{R}\right)$. Elemental analysis calcd (\%) for $\mathrm{C}_{13} \mathrm{H}_{23} \mathrm{NO}_{8}$ : C 48.59, $\mathrm{H}$ 7.21, N 4.36; found: $\mathrm{C} 48.77, \mathrm{H} 7.23, \mathrm{~N}$ 4.42 .

Bis $\{2[($ tert-butyoxycarbonyl)(methyl)amino]ethyl $\} \quad$ (2R.3R)-2,3-dihydroxybutanedioate (14). Starting from $12(1.0 \mathrm{~g}, 1.80 \mathrm{mmol})$ and the title compound was obtained using deprotection method i) (0.82 g, $1.76 \mathrm{mmol}, 97.5 \%) .{ }^{1} \mathrm{H}$ NMR (400 MHz, DMSO-D $): \mathrm{d}$ $=1.39\left(\mathrm{~s}, 18 \mathrm{H} ;-\mathrm{C}\left(\mathrm{CH}_{3}\right)_{3}\right), 2.84\left(\mathrm{~s}, 6 \mathrm{H} ; \mathrm{CH}_{3}-\mathrm{N}-\right), 3.47\left(\mathrm{~m}, 4 \mathrm{H} ;-\mathrm{N}-\mathrm{CH}_{2}-\right), 4.25(\mathrm{~s}, 4 \mathrm{H} ;-$ 
$\left.\mathrm{CH}_{2}-\mathrm{O}-\right), 4.50 \mathrm{ppm}(\mathrm{s}, 2 \mathrm{H} ;-\mathrm{CH}-\mathrm{OH}) .{ }^{13} \mathrm{C}$ NMR (100 MHz, DMSO-D $): \mathrm{d}=28.2(-$ $\left.\mathrm{C}\left(\mathrm{CH}_{3}\right)_{3}\right), 35.1\left(-\mathrm{N}-\mathrm{CH}_{3}\right), 47.4\left(-\mathrm{N}-\mathrm{CH}_{2}-\right), 62.9$ (-CH $\left.\mathrm{CH}_{2}-\mathrm{O}-\right), 72.0$ (-CH-OH), 79.5 ($\left.C\left(\mathrm{CH}_{3}\right)_{3}\right), 155.5\left(-\mathrm{N}-\mathrm{CO}_{2} \mathrm{tBu}\right), 170.4 \mathrm{ppm}\left(-\mathrm{CO}_{2} \mathrm{CH}_{3}\right)$. IR $\mathrm{v}_{\max }$ (neat): 1203, 1433, 1463, $1679,1759,3030,3345 \mathrm{~cm}^{-1}$. Elemental analysis calcd (\%) for $\mathrm{C}_{20} \mathrm{H}_{36} \mathrm{~N}_{2} \mathrm{O}_{10}: \mathrm{C} 51.71, \mathrm{H}$ 7.81, N 6.03; found: C 51.85, H 7.74, N 5.97.

1-Methyl 4-[2-(methylamino)ethyl] (2R,3R)-2,3-dihydroxybutanedioate (3). Starting from 13 (0.583 g; $1.81 \mathrm{mmol})$, using deprotection method ii) gave compound 3 $(0.280 \mathrm{~g}, 1.27 \mathrm{mmol}, 70 \%)$ is achieved as needle-shaped crystals after crystallization from $\mathrm{CH}_{2} \mathrm{Cl}_{2} / \mathrm{EtOH}$. The same compound was produced starting from 9 using procedure iii). m.p. $=123,32^{\circ} \mathrm{C} .{ }^{1} \mathrm{H}$ NMR $\left(400 \mathrm{MHz}, \mathrm{DMSO}_{-} \mathrm{D}_{3}\right): \mathrm{d}=2.60\left(\mathrm{~s}, 3 \mathrm{H} ; \mathrm{CH}_{3}-\mathrm{N}-\right), 3.22$ (s, 2H; -N-CH $\left.2_{2}^{-}\right), 3.66\left(\mathrm{~s}, 3 \mathrm{H} ;-\mathrm{CO}_{2} \mathrm{CH}_{3}\right), 4.28$ (m, 2H; - $\left.\mathrm{CH}_{2}-\mathrm{O}-\right), 4.53$ ppm (m, 2H; $\mathrm{CH}-\mathrm{OH}) .{ }^{13} \mathrm{C}$ NMR $\left(100 \mathrm{MHz}, \mathrm{DMSO}-\mathrm{D}_{3}\right): \mathrm{d}=32.1\left(-\mathrm{N}-\mathrm{CH}_{3}\right), 46.2\left(-\mathrm{N}-\mathrm{CH}_{2}-\right), 51.2(-$ $\left.\mathrm{CO}_{2} \mathrm{CH}_{3}\right), 59.1\left(-\mathrm{CH}_{2}-\mathrm{O}-\right), 71.5(-\mathrm{CH}-\mathrm{OH}), 170.7$ ppm $\left(-\mathrm{CO}_{2} \mathrm{R}\right) . \mathrm{IR} \mathrm{v}_{\max }(\mathrm{KBr}): 1158$, 1253, 1399, 1459, 1694, 1754, 2975, $3470 \mathrm{~cm}^{-1}$. Elemental analysis calcd (\%) for $\mathrm{C}_{8} \mathrm{H}_{15} \mathrm{NO}_{6}$ : C 43.44, H 6.83, N 6.33; found: C 43.67, H 6.92, N 6.52.

(R.R) bis[2-(methylamino)ethyl] tartrate (4). Starting from 14 (0.634 g; $1.36 \mathrm{mmol})$ using deprotection method ii) gave compound $4(0.312,1.18 \mathrm{mmol}, 87 \%)$ as a solid from $\mathrm{CH}_{2} \mathrm{Cl}_{2} / \mathrm{EtOH}$. The same compound was produced starting from $\mathbf{1 0}$ using procedure iii). m.p. $=133.73^{\circ} \mathrm{C} .{ }^{1} \mathrm{H}$ NMR $\left(400 \mathrm{MHz}, \mathrm{DMSO}-\mathrm{D}_{3}\right): \mathrm{d}=2.61\left(\mathrm{~s}, 6 \mathrm{H} ; \mathrm{CH}_{3^{-}}\right.$ $\mathrm{N}-), 3.22\left(\mathrm{~m}, 4 \mathrm{H} ;-\mathrm{N}-\mathrm{CH}_{2}-\right), 4.31$ (m, 4H; - $\left.\mathrm{CH}_{2}-\mathrm{O}-\right)$, 4.63 ppm (d, 2H; J=0.8Hz, -CH$\mathrm{OH}) . d_{C}$ ppm (DMSO-D $\left.6,100 \mathrm{MHz}\right): 32.4\left(-\mathrm{N}-\mathrm{CH}_{3}\right), 46.3\left(-\mathrm{N}-\mathrm{CH}_{2}-\right), 59.7\left(-\mathrm{CH}_{2}-\mathrm{O}-\right)$, $72.0(-\mathrm{CH}-\mathrm{OH}), 170.4 \mathrm{ppm}\left(-\mathrm{CO}_{2} \mathrm{CH}_{3}-\right)$. Elemental analysis calcd (\%) for $\mathrm{C}_{10} \mathrm{H}_{20} \mathrm{~N}_{2} \mathrm{O}_{6}$ : C 45.45, H 7.63, N 10.60; found: C 45.31, H 7.70, N 10.67.

Silsesquioxane derived molecules 
(N-methyl, methylphenylethyl-POSS)-aminoethanol, 15. A solution of chloromethyl)phenylethyl-POSS (1-[2-[(Chloromethyl)phenyl]ethyl]-3,5,7,9,11,13,15heptacyclopentylpentacyclo[9.5.1.1 $\left.1^{3,9} \cdot 1^{5,15} \cdot 1^{7,13}\right]$ octasiloxane $) \quad(1 \quad \mathrm{~g}, \quad 1 \quad \mathrm{mmol})$ in dichloromethane was treated with 2 (1,5 eq) and pyridine $(0,2$ eq). The resultant solutions was heated to reflux and stirred for 24 hours. After reaction completion the solvent was removed under reduced pressure and the crude reaction was suspended in a small quantity of dichloromethane. The product was then recovered by precipitation in acetonitrile in nearly quantitative yield. ${ }^{1} \mathrm{H}$ NMR (400 $\left.\mathrm{MHz}, \mathrm{CDCl}_{3}\right): \delta=0.93(\mathrm{~m} ; 2 \mathrm{H}$; Si- $\left.\mathrm{CH}_{2}-\right), 0.96\left(\mathrm{~m}, 7 \mathrm{H}\right.$; -Si-CH), 1.47, 1.57 and $1.73\left(\mathrm{~m}, 56 \mathrm{H} ;-\left(\mathrm{CH}_{2}\right)-\right), 2.33$ (s, 3H; $\left.\mathrm{CH}_{3}-\mathrm{N}-\right), 2.65$ (m; 2H; -N-CH $\left.2_{2}^{-}\right), 2.71$ (m; 2H; - $\left.\mathrm{CH}_{2}-\mathrm{Ph}-\right), 3.80$ (s, 3H; -O-CH 3 ), 3.83 (m, 2H; - $\left.\mathrm{CH}_{2}-\mathrm{OH}\right), 3.87$ (m, 2H; Ar- $\left.\mathrm{CH}_{2}-\mathrm{N}-\right), 7.24$ and $7.75 \mathrm{ppm}\left(\mathrm{m}, 8 \mathrm{H} ;-\mathrm{CH}^{\mathrm{Ar}}-\right) .{ }^{13} \mathrm{C}$ NMR (100 MHz, $\left.\mathrm{CDCl}_{3}\right): \delta=22.4,27.2\left(C^{\mathrm{Cp}}\right), 41.1\left(\mathrm{CH}_{3}-\mathrm{N}-\right), 49.9(\mathrm{Si}-\mathrm{CH}-), 51.5$ (-O$\left.\mathrm{CH}_{3}\right), 57.1\left(-\mathrm{CH}_{2}-\mathrm{OH}\right), 57.8\left(-\mathrm{Ph}-\mathrm{CH}_{2}-\mathrm{N}\right), 61.4\left(-\mathrm{N}-\mathrm{CH}_{2}-\right), 126.2,129.1,130.2$ and 140.4 ppm (-C Ar $). I R v_{\max }$ (neat): 504, 1115, 1450, 2860, 2950, $3431 \mathrm{~cm}^{-1}$. Elemental analysis calcd (\%) for $\mathrm{C}_{47} \mathrm{H}_{81} \mathrm{NO}_{13} \mathrm{Si}_{8}$ : C 51.66, H 7.47, N 1.28; found: C 51.51, H 7.52, N 1.25 .

16. A solution of $15(0.750 \mathrm{~g}$, in benzene was treated with 7 (1.0 eq) in presence of butylstannonic acid (0,05 eq). The resultant suspension was then refluxed for 3 days, using a dean-stark apparatus to displace the equilibrium, filtered off through a column of florisil and the clean solution concentrated in vacuo to give a yellow solid. The crude product was suspended in $5 \mathrm{~mL}$ of dichloromethane and $50 \mathrm{~mL}$ of acetonitrile were added to precipitate the silsesquioxane products. The title compound was then purified to give a white product by flash chromatography on silica using n-hexane:diethyl ether $(0,725 \mathrm{~g}, 0,53 \mathrm{mmol}, 76 \%) .{ }^{1} \mathrm{H}$ NMR $\left(400 \mathrm{MHz}, \mathrm{CDCl}_{3}\right): \delta=0.91\left(\mathrm{~m}, 2 \mathrm{H} ;-\mathrm{Si}_{-} \mathrm{CH}_{2}-\right)$, $1.00(\mathrm{~m}, 7 \mathrm{H} ;-\mathrm{Si}-\mathrm{CH}), 1.42,1.50$ and $1.72\left(\mathrm{~m}, 56 \mathrm{H} ;-\left(\mathrm{CH}_{2}\right)-\right), 2.41\left(\mathrm{~s}, 3 \mathrm{H} ; \mathrm{CH}_{3}-\mathrm{N}-\right)$, 
2.65 (m; 2H; -N-CH $\left.2_{2}\right), 2.68$ (m; 2H; -CH2-Ph-), 3.68 (m, 2H; - $\left.\mathrm{CH}_{2}-\mathrm{O}-\right), 3.76$ (s, 3H; O-CH$\left.{ }_{3}\right), 3.85$ (m, 2H; Ar-CH2-N-), 5.01 (m, 2H; -CH-O-), 6.17 (s, 1H; -CH-Ph), 7.24, 7.43, $7.75 \mathrm{ppm}\left(\mathrm{m}, 18 \mathrm{H} ; H\right.$-Ar). ${ }^{13} \mathrm{C} \mathrm{NMR}\left(100 \mathrm{MHz}, \mathrm{CDCl}_{3}\right): \delta=22.4$ and $27.2\left(C^{\mathrm{Cp}}\right)$, $40.9\left(\mathrm{CH}_{3}-\mathrm{N}-\right), 49.9$ (Si-CH-), $51.2\left(-\mathrm{O}-\mathrm{CH}_{3}\right), 58.4\left(-\mathrm{Ph}-\mathrm{CH}_{2}-\mathrm{N}\right), 61.9\left(-\mathrm{CH}_{2}-\mathrm{O}-\right), 62.6$ $\left(-\mathrm{N}-\mathrm{CH}_{2}-\right), 80.1$ (-CH-O-), 127.4, 128.5, 130.2, 135.5 and $142.1\left(-C^{\mathrm{Ar}}\right), 169.5$ ppm ($\left.\mathrm{CO}_{2}{ }^{-}\right)$: IR $\mathrm{v}_{\max }$ (neat): 501, 1112, 1450,1746, 2868, $2950 \mathrm{~cm}^{-1}$. Elemental analysis calcd (\%) for $\mathrm{C}_{59} \mathrm{H}_{91} \mathrm{NO}_{18} \mathrm{Si}_{8}$ : C 53.40, H 6.91, N 1.06; found: C 53.47, H 6.74, N 0.98 .

17. The cleavage of the benzilidene acetal group in $\mathbf{1 6}(0.4 \mathrm{~g}, 0.36 \mathrm{mmol})$ was carried out using the same abovementioned deprotection method i) giving $\mathbf{1 7}$ as a white solid after washing with acetonitrile $(0,417 \mathrm{~g}, 0.32 \mathrm{mmol}, 89 \%) .{ }^{1} \mathrm{H}$ NMR (400 MHz, $\left.\mathrm{CDCl}_{3}\right): \delta=0.93\left(\mathrm{~m}, 2 \mathrm{H} ;-\mathrm{Si}-\mathrm{CH}_{2}-\right), 0.97(\mathrm{~m}, 7 \mathrm{H} ;-\mathrm{Si}-\mathrm{CH}), 1.45,1.51$ and $1.73(\mathrm{~m}, 56 \mathrm{H}$; -(CH2)-), 2.39 (s, 3H; $\left.\mathrm{CH}_{3}-\mathrm{N}-\right), 2.67$ (m; 2H; -N-CH $\left.2_{2}^{-}\right), 2.71$ (m; 2H; - $\left.\mathrm{CH}_{2}-\mathrm{Ph}-\right), 3.74$ (m, 2H; - $\left.\mathrm{CH}_{2}-\mathrm{O}-\right), 3.79$ (s, 3H; -O-CH 3 ), 3.83 (m, 2H; Ar- $\mathrm{CH}_{2}-\mathrm{N}-$ ), 4.58 (m, 2H; -CH$\mathrm{OH}), 7.21$ and $7.43 \mathrm{ppm}\left(\mathrm{m}, 8 \mathrm{H} ; H\right.$-Ar). ${ }^{13} \mathrm{C} \mathrm{NMR}\left(100 \mathrm{MHz}, \mathrm{CDCl}_{3}\right): \delta=22.5$ and 27.2 $\left(C^{\mathrm{Cp}}\right), 41.2\left(\mathrm{CH}_{3}-\mathrm{N}-\right), 50.0(\mathrm{Si}-\mathrm{CH}-), 51.4\left(-\mathrm{O}-\mathrm{CH}_{3}\right), 58.0\left(-\mathrm{Ph}-\mathrm{CH}_{2}-\mathrm{N}\right), 62.3\left(-\mathrm{CH}_{2}-\mathrm{O}-\right)$, $62.5\left(-\mathrm{N}-\mathrm{CH}_{2}-\right), 73.0(-\mathrm{CH}-\mathrm{OH}), 127.4,128.5,130.5$ and $141.9\left(-C^{\mathrm{Ar}}\right), 170.9 \mathrm{ppm}(-$ $\mathrm{CO}_{2^{-}}$). IR $\mathrm{v}_{\max }$ (neat): $501,1112,1746,2868,2950,3411 \mathrm{~cm}^{-1}$. Elemental analysis calcd (\%) for $\mathrm{C}_{52} \mathrm{H}_{87} \mathrm{NO}_{18} \mathrm{Si}_{8}$ : C 50.41, H 7.08, N 1.13; found: C 50.29, H 7.04, N 1.19.

General procedure for the asymmetric epoxidation of allylic alcohols

For comparison purposes the chiral ligands prepared accordingly to the above mentioned procedures have been used in the asymmetric epoxidation of several allylic alcohols in presence of titanium isopropoxide as the metallic source and tert-butyl hydroperoxide as the oxidant. In a typical assay $1.0 \mathrm{~g}$ of $4 \mathrm{~A}$ molecular sieves were suspended, under inert atmosphere, in $50 \mathrm{ml}$ of dry $\mathrm{CH}_{2} \mathrm{Cl}_{2}$ before cooling the resultant 
suspension down to $-20^{\circ} \mathrm{C}$. The next step consisted of the addition of $42 \mathrm{mg}$ of freshly distilled $\mathrm{Ti}(\mathrm{OiPr})_{4}(0.15 \mathrm{mmol})$, an equimolar ammount of the chiral ligand $(0.15 \mathrm{mmol})$ and $2.15 \mathrm{~mL}$ of an anhydrous solution of TBHP in dry $\mathrm{CH}_{2} \mathrm{Cl}_{2}(120 \mathrm{mmol})$. The resultant suspension was then stirred for 1 hour before adding the substrate $(30 \mathrm{mmol})$ by dropping during 1 hour using a syringe pump. The reaction was then stirred for another additional hour. The resultant epoxides were then recovered and purified by semi-preparative HPLC. The isolated products were analyzed either by using a GC, fitted with a chiral capillary column (Chiraldex G-TA; $40 \mathrm{~m} \times 0.25 \mathrm{~mm}$ ) and a FID detector, or by HPLC using n-Heptane:Isopropanol in a chiral column ((S,S)-Whelk-01; $25 \mathrm{~cm} \times 2.5 \mathrm{~mm}$ ) fitted with a UV diode-array detector.

\section{References}

[1] Katsuki T, Sharpless KB. The first practical method for asymmetric epoxidation. J Am Chem Soc 1980;102:5974-5976

[2] Martin VS, Woodard SS, Katsuki T, Yamada Y, Ikeda M, Sharpless KB. Kinetic resolution of racemic allylic alcohols by enantioselective epoxidation. A route to substances of absolute enantiomeric purity?. J Am Chem Soc 1981;103:62376240.

[3] Hanson RM, Sharpless KB. Procedure for the catalytic asymmetric epoxidation of allylic alcohols in the presence of molecular sieves. J Org Chem 1986;51:19221925.

[4] The topic 'Sharpless asymmetric epoxidation' gives 581 entries in a search performed on SciFinder Scholar. 
[5] Gao Y, Sharpless KB. Asymmetric synthesis of both enantiomers of Tomoxetine and Fluoxetine. Selective reduction of 2,3-Epoxycinnamyl alcohol with Red-Al. J Org Chem 1988;53:4081-4084.

[6] Katsuki T, Martin VS. Organic Reactions. New York: Wiley; 1996. 1-299 p.

[7] Canali L, Karjalainen JK, Sherrington DC, Hormi O. Efficient polymer-supported sharpless alkene epoxidation catalyst. Chem Commun 1997:123-124.

[8] Meunier D, Piechaczyk A, de Mallmann A, Basset JM. Silica supported tantalum catalysts for asymmetric epoxidations of allylic alcohols. Angew Chem Int Ed 1999;38:3540-3542.

[9] Xiang S, Zhang Y, Xin Q, Li C. Asymmetric epoxidation of allylic alcohol on organic-inorganic hybrid chiral catalysts grafted onto the surface of silica and in the mesopores of MCM-41. Angew Chem Int Ed Engl 2002;41:821-824.

[10] Zhao W, Hao ZP, Hu C, Li J, Xu X. The epoxidation of allylic alcohol on Ticomplex/MCM-48 catalysts. Microporous Mesoporous Mater 2008;112:133-137.

[11] Riollet V, Quadrelli EA, Copéret C, Basset JM, Andersen RA, Köhler K, Böttcher RM, Herdtweck E. Grafting of $\left[\mathrm{Mn}\left(\mathrm{CH}_{2} \mathrm{tBu}\right)_{2}(\right.$ tmeda $\left.)\right]$ on silica and comparison with its reaction with a silsesquioxane. Chem Eur J 2005;11:7358-7365.

[12] Mintcheva N, Tanabe M, Osakada K. Preparation and structure of new phenylplatinum complexes containing silsesquioxane as a monodentate or bidentate ligand. Organometallics 2006;25:3776-3783.

[13] Pérez Y, Pérez Quintanilla D, Fajardo M, Sierra I, del Hierro I. Immobilization of titanium chiral alkoxides on SBA-15 and modelling the active sites of heterogeneous catalyst using titanium silsesquioxane complexes. J Mol Catal A 2007;271:227-237. 
[14] Kawasaki T, Ishikawa K, Sekibata H, Sato I, Soai K. Enantioselective synthesis induced by chiral organic-inorganic hybrid silsesquioxane in conjunction with asymmetric autocatalysis. Tetrahedron Lett 2004;45:7939-7941.

[15] Ionescu G, van der Vlugt Jl, Abbenhuis HCL, Vogt D. Synthesis and applications of chiral phosphite ligands derived from incompletely condensed silsesquioxane backbones. Tetrahedron Asymmetry 2005;16:3970-3975.

[16] Barlow JS, Dixon DJ, Foster AC, Ley SV, Reynolds DJ. New building blocks for efficient and highly diastereoselective polyol production - synthesis and utility of $\left(R^{\prime}, R^{\prime}, S, S\right)$ and $\left(S^{\prime}, S^{\prime}, R, R\right)-2,3$-butane diacetal protected butane tetrol derivatives. J Chem Soc Perkin Trans 1 1999;12:1627-1630.

[17] Seebach D. Modern Synthetic Methods. Frankfurt/Main: Wiley. 1980. 113-171 p.

[18] Dixon DJ, Foster AC, Ley SV, Reynolds DJ. Preparation of desymmetrised mesotartrate derivatives - synthesis and utility of $\left(R^{\prime}, R^{\prime}, S, R\right)-2,3-$ butane diacetal procected butane tetrol. J Chem Soc Perkin Trans 1 1999;12:1631-1633.

[19] Uri A, Tuulmets A, Palm V. Transesterification of esters of carboxylic acids by titanium-alcoholates 2. Transesterification of esters of aromatic acids. Organic Rectivity (Tartu) 1983;20:122-131.

[20] Furlán RLE, Mata EG, Mascaretti OA. Butylstannonic acid catalyzed transesterification of carboxylic esters. Tetrahedron Lett 1998;39:2257-2260.

[21] Kociensky PJ. Protecting groups. Sttutgart: Thieme. 1994. 96-102 p.

[22] Shimizu I, Matsumoto $\mathrm{Y}$, Shoji K, Ono T, Satake A, Yamamoto A. Enantioselective elimination reaction of a 6,6-Membered Bicyclic Allylic Carbonate. Importance of chirality reversal depending on the palladium-chiral phosphine ratio. Tetrahedron Lett 1996;37:7115-7118. 
[23] Altava B, Berruguete MI, Fraile JM, Garcia JI, Luis SV, Mayoral JA, Vicent MJ. How important is the inner matrix of supported enantiomeric catalysts? Reversal of topicity with two polystyrene backbones. Angew Chem Int Ed 2000;39:15031506.

[24] Trost BM, Fettes A, Shireman BT. Direct catalytic asymmetric aldol additions of methyl ynones. Spontaenous reversal in the sense of enantioinduction. J Am Chem Soc 2004;126:2660-2661.

[25] Arseniyadis S, Valleix A, Wagner A, Miokowski C. Kinetic resolution of amines: a highly enantioselective and chemoselective acetylating agent with a unique solvent-induced reversal of stereoselectivity. Angew Chem Int Ed 2004;43;33143317.

[26] Altava B, Berruguete MI, Garcia-Verdugo E, Luis SV, Vicent MJ. Functional monolytic resins for the development of enantioselective versatile catalytic minireactors with long-term stability: TADDOL supported systems. Green Chem 2006;8:717-726.

[27] Reed NN, Dickerson TJ, Boldt GE, Janda KD. Enantioreversal in the Sharpless asymmetric epoxidation reaction controlled by the molecular weight of a covalently appended achiral polymer. J Org Chem 2005;70:1728-1731.

[28] Lutz F, Igarashi T, Kawasaki T, Soai K. Small amounts of chiral b-amino alcohols reverse the enantioselectivity of chiral catalysts in cooperative asymmetric autocatalysis. J Am Chem Soc 2005; 127:12206-12207.

[29] Gao Y, Hanson RM, Klunder JM, Ko Soo Y, Masamune H, Sharpless KB. Catalytic asymmetric epoxidation and kinetic resolution: modified procedures including in situ derivatization. J Am Chem Soc 1987;109:5765-5780. 
<smiles>COC(=O)[C@H](O)[C@@H](O)C(=O)OC</smiles><smiles>CNCCO</smiles><smiles>CNCCOC(=O)[C@@H](O)[C@@H](O)C(=O)OC</smiles>

2<smiles>CNCCOC(=O)[C@@H](O)[C@@H](O)C(=O)OCCNC</smiles>

Scheme 1<smiles>COC(=O)[C@H](O)[C@@H](O)C(=O)OC</smiles>

Scheme 2

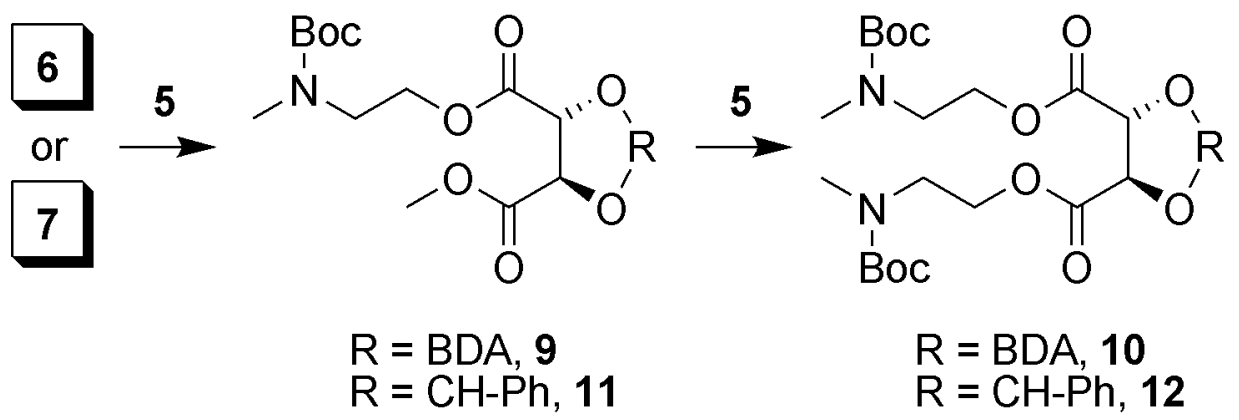

Scheme3 

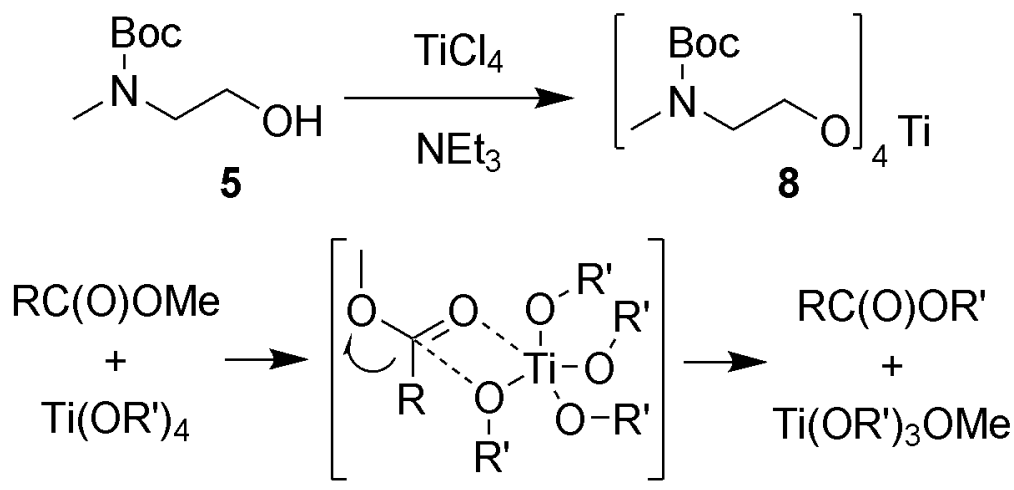

Scheme 4

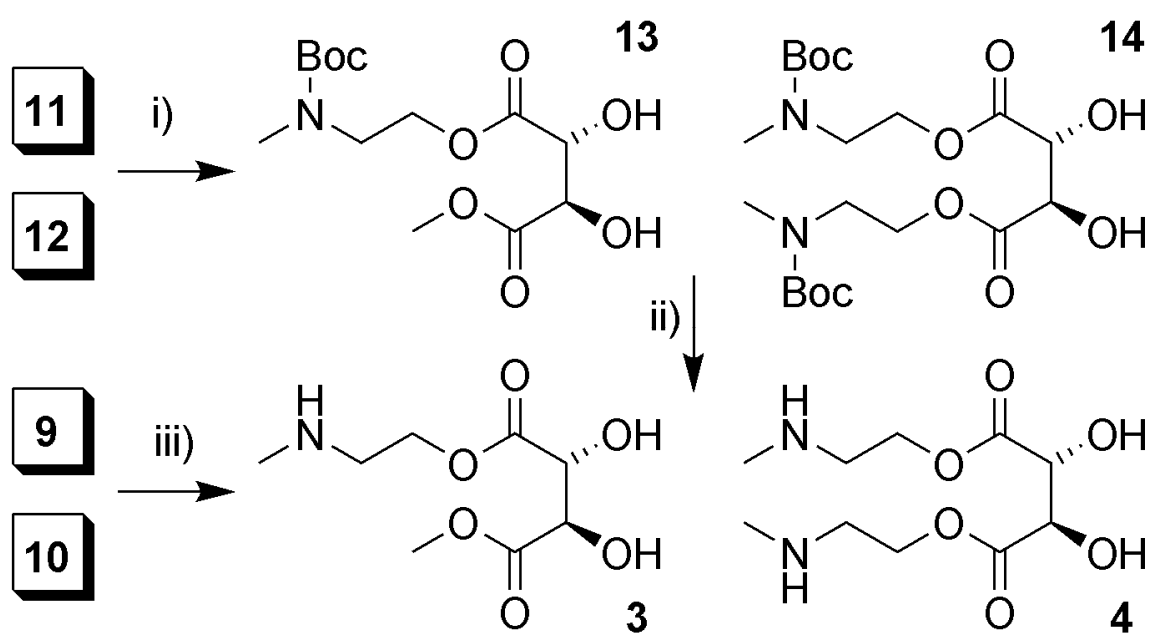

Scheme 5 